\title{
Relation between dust exposure and lung function in miners and ex-miners
}

\author{
C A SOUTAR AND J F HURLEY \\ From the Institute of Occupational Medicine, Edinburgh EH8 9SU, UK
}

ABSTRACT A sample of men working in the British coal industry in the 1950s has been followed up and examined 22 years later. The relations between lung function and individual cumulative exposure to respirable dust have been studied in 1867 men who were still working in the industry at the time of follow up and 2192 men who had left. Levels of forced expired volume in one second $\left(F_{1}\right)$, forced vital capacity (FVC), and $\mathrm{FEV}_{1} / \mathrm{FVC}$ ratio at follow up were found to be inversely related to exposure to respirable dust after allowing for other factors, even in men without pneumoconiosis. The magnitude of this estimated effect was equivalent to a loss of $228 \mathrm{ml} \mathrm{FEV}_{1}$ in response to an exposure of $300 \mathrm{gh} / \mathrm{m}^{3}$, a moderately high exposure for this group. Ex-miners aged under 65 had worse lung function than miners on average, suggesting that ill health had encouraged some of these men to leave the industry. Whereas a more severe response to dust exposure among ex-miners under 65 was suggested, this difference could easily have arisen by chance. The presence of symptoms of chronic bronchitis was associated with reduced levels of lung function, however, and, additionally, ex-miners under 65 with chronic bronchitis showed a more severe response of the FVC to dust exposure than miners without these symptoms. Among these ex-miners with chronic bronchitis a small group of men who had taken other jobs showed a much more severe effect of dust exposure on their lung function than the average, likely in heavily exposed men to contribute importantly to disability. Men in this group who had given up smoking showed an even more severe effect of dust exposure, equivalent to a loss of $940 \mathrm{ml} \mathrm{FEV}$ in response to an exposure of $300 \mathrm{gh} / \mathrm{m}^{3}$. These results indicate that exposure to respirable dust can occasionally cause severe respiratory impairment in the absence of progressive massive fibrosis. Dust exposure was related to a parallel reduction of $\mathrm{FEV}_{1}$ and FVC, implying that the pathology of dust induced lung damage differs from that induced by smoking. This pattern of abnormality was shown by some non-smokers, whereas. smokers and ex-smokers apparently severely affected by dust showed a classic obstructive pattern of abnormality with pronounced reduction of the $\mathrm{FEV}_{1} / \mathrm{FVC}$ ratio.

Studies of British miners without progressive massive fibrosis have shown that lung function is related to the mass of respirable dust to which men are exposed during their working life. ${ }^{1}$ Studies in West Germany have also shown an inverse relation between lung function and estimated exposure to respirable dust, ${ }^{2}$ and in the United States lung function has been shown to be inversely related to years worked underground. ${ }^{3}$

These studies were based on men still at work in the coal industry; and, since ill-health may influence some men to leave their work, it has not been clear whether

Accepted 17 June 1985 the quantitative dust/disease relation estimated applied to all miners generally, or whether some men who had left the industry had suffered greater response to dust exposure than had been observed in working miners.

The first aim of the present study was to confirm the previous finding of a relation between exposure to respirable dust and level of lung function, using a more representative group of British miners, better measures of dust exposure and of smoking habits, and a wider range of lung function measurements than before. The second and main aim was to examine whether men who left the coal industry had different lung function from those who remained and, in particular, a different response to dust. Both aims required that the overall relation found be checked 
for consistency by special study of selected subgroups of men who might have experienced a more severe effect of dust exposure on their lung function than average.

A sample of men who had been working in the 1950s in the 24 collieries of the Pneumoconiosis Field Research of the British National Coal Board ${ }^{4}$ has been followed up and re-examined 21 or more years later. Selected preliminary results from these analyses have been reported in brief elsewhere ${ }^{56}$ and we now describe in full the relation between individual cumulative exposure to respirable dust and level of lung function at follow up examination in the whole group and in subgroups of special interest.

\section{Subjects and methods}

The men studied were included in a sample ${ }^{7}$ of 17738 coal miners who were examined between 1953 and 1958 at medical surveys of the current working populations of 24 collieries in Britain. ${ }^{4}$ This was the first of a series of surveys of working miners carried out at roughly five year intervals as part of the Pneumoconiosis Field Research. A full size chest radiograph was taken at all surveys. The earliest complete set of reliable measurements of lung function were obtained between 1963 and 1968 at the third of this series of medical surveys, attended by 8128 men in the sample who were still employed in the industry at that time. The exclusion of men with progressive massive fibrosis (PMF) at that time, and others with missing or unreliable survey data, reduced those available for lung function study to 7624 men.

After the third survey the routine five yearly examinations were discontinued at 14 ("non-retained") collieries. All 24 coalmines, however, were again included in a series of follow up surveys between 1974 and 1980, aimed at re-examining survivors among the 17738 men whether or not they were still working in the industry. Thirty four per cent had died by the time of follow up surveys, identified by government agencies during a recent mortality study. ${ }^{8}$ These included $1305(17 \%)$ of the 7624 men. When possible other men were traced by examination of colliery and union records, consultation with colliery and union officials, friends, and neighbours, and the help (without the release of confidential information) of the Department of Health and Social Security. Those traced were invited to a further follow up medical survey that allowed the re-examination of $7118 \mathrm{men}$, including $4833(63 \%)$ of the 7624 men who had previously attended the third round of surveys. We restricted attention to these $\mathbf{4 8 3 3}$ so that the data considered now may also be used in a longitudinal study of lung function in the same group of men, to be reported separately. We have also begun a separate investigation of the representativeness of the 4833 men relative to the group of 7624 of which the formed a part.

At the third survey in the mid-1960s and again a the follow up survey, forced expired volume in one second $\left(\mathrm{FEV}_{1}\right)$ and forced vital capacity (FVC) were measured by trained personnel, using two modified Gaensler spirometers, with regular and careful cali $\bar{\alpha}$ bration checks of the instruments and repeated interes observer comparisons throughout the period of the research. $^{1}$

The mean of measurements from three technically satisfactory forced expirations was used for the analysis of $\mathrm{FEV}_{1}$ and $\mathrm{FVC}$, and the $\mathrm{FEV} / \mathrm{FVC}$ ratio was calculated from these means. When men could provide only one or two technically satisfactorit blows, these data were accepted. Standing heightis without shoes, and weight were also measured Trained personnel administered a questionnaire of respiratory symptoms and smoking habit ${ }^{9}$ and chronic bronchitis at follow up survey was defined on the basis of the questionnaire as the presence of per? sistent cough and persistent sputum.

Men were classified by smoking habit as current $\overrightarrow{0}$ smokers (including cigarettes, cigars, or pipe smok@ ing), ex-smokers, or lifelong non-smokers at follow up on the basis of their responses to the smoking questionnaires. Two approximate indices of cigarette consumption were derived as follows, but only fo응 2450 men who were current smokers of cigarettes an $\$ 2$ not pipes or cigars at the third survey in the $1960 \mathrm{~s}$ Firstly, the number of cigarettes smoked at the time of third survey was multiplied by the number of years since the man was aged 16 and expressed as the totat number of cigarettes smoked. Then the number smoked at the time of follow up survey was multiplie similarly by the duration of the interval between thir $\Phi$ and follow up surveys. The number of cigarettes smoked during this interval had not been recorded for men who had given up smoking between third an£ follow up surveys, and a value of zero cigarette con sumption was assigned to them over this period. 음

All follow up survey chest radiographs were read independently and in random order by a panel of five. readers (four of whom were not medically qualified who had trained themselves ${ }^{10}$ to interpret ches? radiographs according to the ILO U/C Clas sification. ${ }^{11}$ The median of these five readings was used as the follow up survey classification for eacte man.

To estimate an individual's exposure to respirablळ్ dust each research colliery population was catego? rised according to a changing series of occupationato groups designed to include within each group mer? who were exposed to similar dust conditions. Afteß the research began in the 1950 s, colliery payment sys $\vec{\alpha}$ 
tems, noting daily job description and location within the colliery for all workmen attending, were summarised in terms of individual attendance in the occupational groups. For the period before the start of the research, or when men transferred to another colliery, or at the 14 non-retained collieries where detailed monitoring was discontinued after the first 10 years, employment histories were obtained by interview at the medical surveys, and each man's coalmining occupations during the period were grouped into six broad environmental categories (much fewer in number and less accurate in dust exposure estimates than the changing series of occupational groups used to calculate directly measured exposures).

Detailed monitoring of airborne respirable dust concentrations in all occupational groups in the 24 collieries was carried out for an approximately 10 year period between the first and third surveys. Subsequently, monitoring was continued only in the 10 retained collieries. Different types of measuring instruments were used, the standard thermal precipitator over the first 10 year period and thereafter the Mining Research Establishment gravimetric sampler, type 113A, which allowed the mass of respirable particles to be measured, selected by their aerodynamic diameter according to the Johannesburg convention. ${ }^{12}$ All dust concentrations from the first 10 year period were later expressed in equivalent gravimetric terms. ${ }^{13}$

The average respirable dust concentrations to which men were exposed over various periods without detailed environmental monitoring were estimated from the detailed environmental measurements, by combining these data according to the six broad environmental categories. At each colliery concentrations existing in these categories before the start of the research were assumed to be the same as the average concentrations there during the subsequent 10 years, and conditions in non-research collieries were assumed to be similar to those in the man's research colliery. Estimates of dust concentrations after the first 10 years in the 14 non-retained collieries were derived from the National Coal Board's dust control measurements of coalface control point concentrations, by applying appropriate conversion factors for the broad environmental categories based on the period when both dust control measurements and detailed research measurements were being made.

The hours each man worked in each occupational group or broad category of occupation were multiplied by the appropriate respirable dust concentrations, summed to give each individual's cumulative exposure to respirable coalmine dust, and expressed in units of gramme hours per cubic metre of sampled air. The measurements of respirable dust concentrations and recording of occupational histories have been described in greater detail elsewhere. ${ }^{1314}$ From the occupational histories, ex-miners were classified as having retired from work, left to take up other work, or been made redundant.

\section{STATISTICAL METHODS}

Following detailed graphical and tabular displays of the data, levels of lung function at follow up survey were compared in cross sectional analyses with other characteristics of the men, using multiple linear regression methods. Residuals were examined in detail. The statistical significance of individual coefficients was assessed using Student's $t$ distribution which, with over 4000 degrees of freedom, was approximately normally distributed. Thus, for example, values of $t$ greater than 1.96 and 2.68 indicate statistical significance at the $5 \%$ and $1 \%$ levels, respectively.

Each of the three lung function measurements $\left(\mathrm{FEV}_{1}, \mathrm{FVC}\right.$, and the ratio $\left.\mathrm{FEV}_{1} / \mathrm{FVC}\right)$ was analysed separately. Transformations of the ratio $\mathrm{FEV}_{1} / \mathrm{FVC}$ were explored, but without clear improvement in the fit of the models to the data. The analyses reported here refer to the ratio in its original percentage units.

\section{CHOICE OF EXPLANATORY VARIABLES}

The analysis was planned to describe the relation of respirable dust to level of lung function, overall and in subsets of the data. There was no attempt to describe comprehensively the role of non-occupational factors, including smoking. Rather we aimed to take account of these sufficiently so that the effect of dust exposure could be estimated reliably. Height and weight were included as ordinary terms in the analysis. The relation of lung function level to age is known to vary according to smoking habit. ${ }^{1}$ Such differences were again found in these data ${ }^{5}$ and were taken into account in the analysis. Other ways of representing the effect of smoking were investigated, and the sensitivity of the estimated dust effect to such changes was monitored in the subgroup of men for whom approximate estimates of lifetime cigarette consumption could be made.

Levels of standardised lung function are known to vary within Britain, and so the 24 collieries were formed into six groups according to geographical proximity. Average differences in lung function between these groups were included in the regression models. Regional differences in the relation between $\mathrm{FEV}_{1}$ and dust exposure have been described elsewhere. ${ }^{5}$

No adjustments were made in the first instance for presence of respiratory symptoms or of coalworkers' simple pneumoconiosis because such characteristics 
Table 1 Characteristics of men at the time of follow up survey. (Standard deviations or percentages in parentheses)

\begin{tabular}{|c|c|c|c|}
\hline & Miners & Ex-miners $<65$ & Ex-miners $\geqslant 65$ \\
\hline $\begin{array}{l}\text { No of men } \\
\text { Age (years) } \\
\text { Height }(\mathrm{cm}) \\
\text { Weight }(\mathrm{kg}) \\
\left.{\text { Dust exposure }\left(\mathrm{gh} / \mathrm{m}^{3}\right)}^{\mathbf{3}}\right) \\
\text { FEV }(\mathrm{ml}) \\
\mathrm{FVC}(\mathrm{ml}) \\
\mathrm{FEV}_{1} / \mathrm{FVC} \text { ratio }(\%) \\
\text { No of non-smokers } \\
\text { No of smokers } \\
\text { No of ex-smokers } \\
\text { No of men with small rounded } \\
\text { opacities in chest radiograph }\end{array}$ & $\begin{array}{c}1867 \\
53(7) \\
171(6) \\
76(12) \\
174(100) \\
2751(759) \\
3744(851) \\
73(10) \\
255(14 \%) \\
1177(63 \%) \\
435(23 \%)\end{array}$ & $\begin{array}{c}1023 \\
56(8) \\
170(6) \\
75(13) \\
167(107) \\
2485(834) \\
3477(935) \\
70(12) \\
125(12 \%) \\
625(61 \%) \\
273(27 \%)\end{array}$ & $\begin{array}{c}1169 \\
70(3) \\
168(6) \\
72(12) \\
208(120) \\
1874(654) \\
2835(752) \\
65(12) \\
134(11 \%) \\
683(58 \%) \\
352(30 \%)\end{array}$ \\
\hline $\begin{array}{l}\text { Categories } 0 / 1 \text { to } 1 / 2 \\
\text { Categories } 2 / 1 \text { or greater } \\
\text { No of men with chronic cough and sputum }\end{array}$ & $\begin{array}{l}389(21 \%) \\
104(6 \%) \\
733(39 \%)\end{array}$ & $\begin{array}{c}221(22 \%) \\
67(7 \%) \\
453(44 \%)\end{array}$ & $\begin{array}{l}286(24 \%) \\
115(10 \%) \\
555(47 \%)\end{array}$ \\
\hline
\end{tabular}

$\mathrm{gh} / \mathrm{m}^{3}=$ Gramme hours/cubic metre.

are themselves (at least in part) a response to dust exposure. ${ }^{914}$ Stratification of the data subsequently by presence or absence of symptoms proved informative, however, and a search for men who might have suffered a greater than average effect of dust on their respiratory health prompted an examination of men with respiratory symptoms who had left the industry before normal retiral age, on the rationale that ill health might have influenced these men in their decision to leave.

\section{Results}

\section{STUDY GROUP}

The exclusion of men with incomplete or unreliable information at either third or follow up survey, or $\overrightarrow{-}$ whose follow up radiograph showed progressive mas- $₫$ sive fibrosis as classified by three or more of the five. readers, led to a study group of $\mathbf{4 0 5 9}$ men. Of those, $\mathrm{O}$ $1867(46 \%)$ were miners and still in the industry at the time of follow up survey; $1023(25 \%)$ were ex-miners
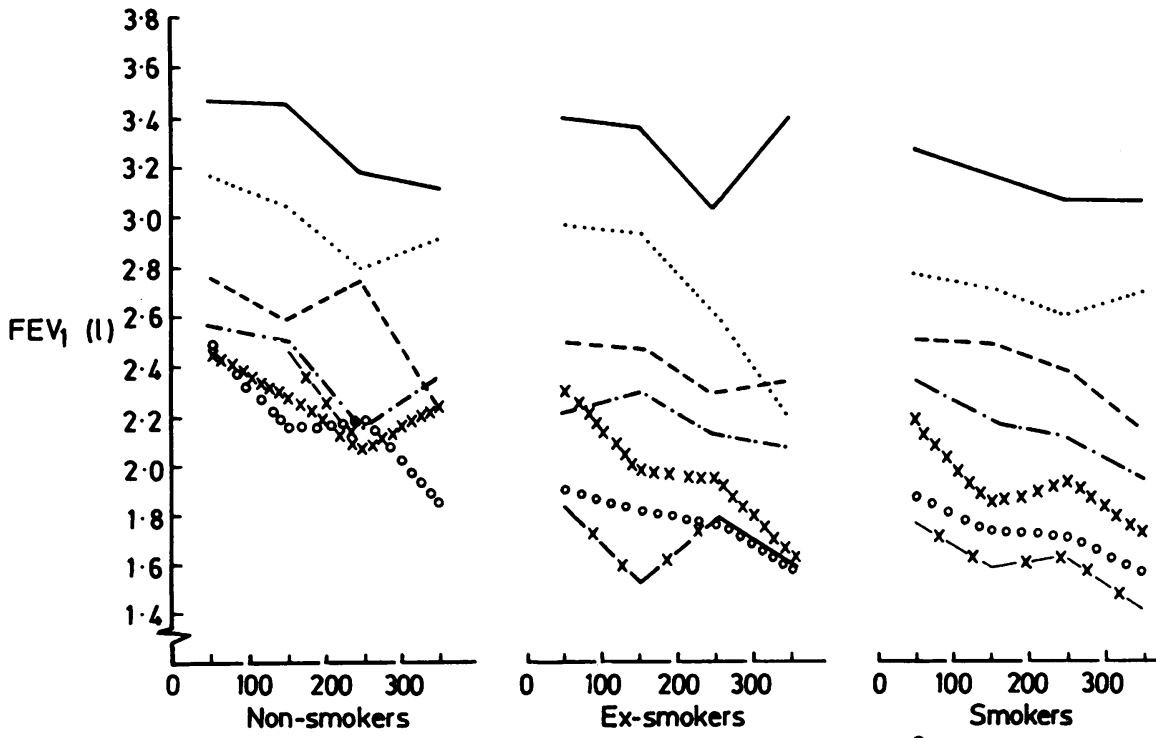

\section{Dust exposure ranges $\left(\mathrm{gh} / \mathrm{m}^{3}\right)$}

Fig 1 Mean observed FEV ${ }_{1}$ by dust exposure ranges for all miners and ex-miners. Groups consisting of one man, without men in adjacent dust exposure groups, have been omitted. 
Table 2 Coefficients for multiple regression models of $F E V_{1}, F V C$, and $F E V_{1} / F V C$ ratio at follow up survey

\begin{tabular}{|c|c|c|c|c|c|c|}
\hline & \multicolumn{2}{|l|}{$F E V_{1}(m l)$} & \multicolumn{2}{|l|}{$F V C(\mathrm{ml})$} & \multicolumn{2}{|c|}{$F E V_{1} / F V C$ ratio (\%) } \\
\hline & Coefficient & $t$ & Coefficient & $t$ & Coefficient & $t$ \\
\hline $\begin{array}{l}\text { Effect of age (years) in non-smokers } \\
\text { Difference in effect of age (years), }\end{array}$ & -41 & $-14 \cdot 4^{* * *}$ & -42 & $-13 \cdot 6^{* * *}$ & -0.19 & $-13 \cdot 9 * * *$ \\
\hline $\begin{array}{l}\text { compared with non-smokers, in: } \\
\text { Ex-smokers } \\
\text { Current smokers } \\
\text { Difference in mean level, } \dagger \text { compared }\end{array}$ & $\begin{array}{l}-7 \\
-8\end{array}$ & $\begin{array}{l}-2 \cdot 2^{*} \\
-2 \cdot 5^{*}\end{array}$ & $\begin{array}{l}-4 \\
-8\end{array}$ & $\begin{array}{l}-1 \cdot 3 \\
-2 \cdot 3 *\end{array}$ & $\begin{array}{l}-0 \cdot 21 \\
-0 \cdot 15\end{array}$ & $\begin{array}{l}-4 \cdot 2^{* * * *} \\
-2 \cdot 6^{* *}\end{array}$ \\
\hline $\begin{array}{l}\text { with non-smokers, in: } \\
\text { Ex-smokers } \\
\text { Current smokers } \\
\text { Height (cm) } \\
\text { Weight (kg) } \\
\text { Difference in mean level, compared }\end{array}$ & $\begin{array}{c}-279 \\
-216 \\
27 \\
1 \cdot 7\end{array}$ & $\begin{array}{l}-8 \cdot 8^{* * * *} \\
-6 \cdot 1^{* * * *} \\
15 \cdot 0^{* * *} \\
1 \cdot 7\end{array}$ & $\begin{array}{l}-184 \\
-137 \\
48 \\
-4 \cdot 3\end{array}$ & $\begin{array}{l}-0 \cdot 3 \\
-1 \cdot 7 \\
24 \cdot 5^{* * *} \\
-4 \cdot 1^{* * *}\end{array}$ & $\begin{array}{r}-4 \cdot 65 \\
-4 \cdot 10 \\
-0 \cdot 22 \\
0 \cdot 15\end{array}$ & $\begin{array}{l}-2 \cdot 7^{* *} \\
-1 \cdot 5 \\
-7 \cdot 2^{* * *} \\
9 \cdot 3^{* * *}\end{array}$ \\
\hline $\begin{array}{l}\text { with miners, in: } \\
\text { Ex-miners }<65 \\
\text { Ex-miners } \geqslant 65 \\
\text { Dust exposure }\left(\mathrm{gh} / \mathrm{m}^{3}\right) \\
\text { Constant } \ddagger \\
\text { Difference in mean level from } \\
\text { Scottish region for: }\end{array}$ & $\begin{array}{l}-83 \\
21 \\
-0 \cdot 76 \\
2848\end{array}$ & $\begin{array}{l}-3 \cdot 3^{* * *} \\
0 \cdot 6 \\
-7 \cdot 4^{* * *} \\
-\end{array}$ & $\begin{array}{l}-41 \\
44 \\
-0 \cdot 92 \\
3599\end{array}$ & $\begin{array}{l}-1 \cdot 4 \\
1 \cdot 1 \\
-8 \cdot 2^{* * *}\end{array}$ & $\begin{array}{l}-2.0 \\
-1.7 \\
-0.005 \\
79.9\end{array}$ & $\begin{array}{l}-4 \cdot 7^{* * * *} \\
-2 \cdot 9^{* *} \\
-2 \cdot 7^{* *} \\
-\end{array}$ \\
\hline $\begin{array}{l}\text { North east England } \\
\text { Yorkshire and Nottinghamshire } \\
\text { West Midlands } \\
\text { South Wales } \\
\text { Others }\end{array}$ & $\begin{array}{l}-92 \\
-36 \\
-86 \\
-179 \\
-90\end{array}$ & $\begin{array}{l}-2 \cdot 7^{* *} \\
-0 \cdot 1 \\
-2 \cdot 3^{*} \\
-5 \cdot 2^{* * *} \\
-2 \cdot 5^{*}\end{array}$ & $\begin{array}{r}96 \\
268 \\
184 \\
-46 \\
98\end{array}$ & $\begin{array}{l}2 \cdot 6^{* *} \\
6 \cdot 6^{* * *} \\
4 \cdot 4^{* * *} \\
-1 \cdot 2 \\
2 \cdot 4^{*}\end{array}$ & $\begin{array}{l}-4 \cdot 7 \\
-6 \cdot 6 \\
-6 \cdot 6 \\
-4 \cdot 3 \\
-4 \cdot 7\end{array}$ & $\begin{array}{r}-8 \cdot 3^{* * *} \\
-10 \cdot 7^{* * *} \\
-10 \cdot 3^{* * *} \\
-7 \cdot 3^{* * *} \\
-7 \cdot 7^{* * *}\end{array}$ \\
\hline
\end{tabular}

${ }^{* 0} 0.05>p \geqslant 0.01 ;{ }^{* *} 0.01 \geqslant p>0.001 ;{ }^{* * *} p<0.001$.

tAt age 60, zero dust exposure.

$\ddagger$ Non-smoking miners in Scotland (age 60 , height $170 \mathrm{~cm}$, weight $75 \mathrm{~kg}$, zero dust exposure).

under 65, who therefore had left the industry before the normal retirement age; and the remaining 1169 $(29 \%)$ were ex-miners over 65 , including men who had retired at the normal retirement age as well as men who had left prematurely. Characteristics of men at the time of follow up survey are illustrated in table 1 .

\section{DUST EXPOSURE AND LUNG FUNCTION}

Figure 1 shows the mean observed values of $\mathrm{FEV}_{1}$ for all 4059 men. The effects of age and the smoking habit are obvious, and an inverse relation between FEV and dust exposure is apparent in almost all age and smoking groups.
Table 2 shows the estimated relation of $\mathrm{FEV}_{1}$, FVC, and $\mathrm{FEV}_{1} / \mathrm{FVC}$ ratio with age, height, weight, smoking habit, and geographical region. The coefficients for age and height, and increased loss of function with age in smokers are consistent with other published studies and establish this model as an adequate basis for examining the effects of dust exposure. In this context $F V_{1}, F V C$, and $F E V_{1} / F V C$ ratio were each found to be inversely related to exposure to respirable dust (table 2). The coefficients for the lung function variables represent the average estimated relation between dust exposure and the functional variable in question, after adjusting for other factors. As with the coefficients for age, height, weight, and

Table 3 Estimated effect of dust within smoking groups. (These coefficients are taken from the statistical model described in table 2, after addition of separate terms for dust exposure according to smoking habit)

\begin{tabular}{|c|c|c|c|c|c|c|}
\hline & \multicolumn{2}{|l|}{$F E V_{1}(m l)$} & \multicolumn{2}{|l|}{$F V C(m l)$} & \multicolumn{2}{|c|}{$F E V_{1} / F V C$ ratio (\%) } \\
\hline & Coefficient & $t$ & Coefficient & $t$ & Coefficient & $t$ \\
\hline $\begin{array}{l}\text { Effect of dust exposure }\left(\mathrm{gh} / \mathrm{m}^{3}\right) \text { in: } \\
\text { Non-smokers } \\
\text { Ex-smokers } \\
\text { Current smokers } \\
\text { Difference in mean level } \dagger \text { compared }\end{array}$ & $\begin{array}{l}-0.90 \\
-0.93 \\
-0.65\end{array}$ & $\begin{array}{l}-3 \cdot 3 * * \\
-5 \cdot 1 * * * \\
-5 \cdot 2 * * *\end{array}$ & $\begin{array}{l}-1 \cdot 03 \\
-1 \cdot 14 \\
-0.80\end{array}$ & $\begin{array}{l}-3 \cdot 4 * * * \\
-5 \cdot 6 * * * \\
-5 \cdot 8 * * *\end{array}$ & $\begin{array}{l}-0.004 \\
-0.006 \\
-0.004\end{array}$ & $\begin{array}{l}-0.8 \\
-2.0^{*} \\
-1.9\end{array}$ \\
\hline $\begin{array}{l}\text { with non-smokers in: } \\
\text { Ex-smokers } \\
\text { Current smokers } \\
\text { Effect of age (years) in non-smokers } \\
\text { Difference in effect of age (years) }\end{array}$ & $\begin{array}{r}-212 \\
-327 \\
-40\end{array}$ & $\begin{array}{c}1 \cdot 5 \\
0 \cdot 7 \\
-13 \cdot 6^{* * *}\end{array}$ & $\begin{array}{r}-119 \\
-228 \\
-42\end{array}$ & $\begin{array}{r}1 \cdot 8 \\
0 \cdot 3 \\
-12 \cdot 8\end{array}$ & $\begin{array}{l}-3 \cdot 7 \\
-4 \cdot 9 \\
-0 \cdot 19\end{array}$ & $\begin{array}{c}1 \cdot 5 \\
2 \cdot 7^{* *} \\
-3 \cdot 8^{* * *}\end{array}$ \\
\hline $\begin{array}{l}\text { Ex-smokers } \\
\text { Current smokers }\end{array}$ & $\begin{array}{l}-8 \\
-7\end{array}$ & $\begin{array}{l}-2 \cdot 4^{*} \\
-2 \cdot 4^{*}\end{array}$ & $\begin{array}{l}-8 \\
-5\end{array}$ & $\begin{array}{c}-2 \cdot 2^{*} \\
1 \cdot 4\end{array}$ & $\begin{array}{l}-0.14 \\
-0.21\end{array}$ & $\begin{array}{l}-2 \cdot 4^{*} \\
-4 \cdot 0^{* * * *}\end{array}$ \\
\hline
\end{tabular}

*0.05>p $\geqslant 0.01 ; * 0.01>p \geqslant 0.001 ; * * * p<0.001$.

†At age 60, zero dust exposure. 
smoking habit, the magnitude and arithmetic sign of the dust exposure coefficient may be informative, as well as its statistical significance. The size of the coefficient for $\mathrm{FEV}_{1}$, for instance, was $-0.76 \mathrm{ml} \mathrm{FEV} / \mathrm{gh} / \mathrm{m}^{3}$ of exposure $(95 \%$ confidence limits were -0.56 to -0.95 ). This coefficient is equivalent to a loss of $228 \mathrm{ml} \mathrm{FEV}$ in relation to a moderately high lifetime dust exposure of $300 \mathrm{gh} / \mathrm{m}^{3}$. The statistical model illustrated in table 2 accounted for $40 \%$ of the variation in both FEV 1 and FVC and $20 \%$ of the variation in $\mathrm{FEV}_{1} / \mathrm{FVC}$ ratio.

The effects of dust exposure on FEV 1 and FVC were still clearly seen within each of the three smoking categories, and overall the effect of dust exposure was no less severe in non-smokers than in smokers. For instance, the estimated effect of dust on $\mathrm{FEV}_{1}$ was $-0.90 \mathrm{ml} \mathrm{FEV} / \mathrm{gh} / \mathrm{m}^{3}$ for non-smokers. Table 3 shows the estimated effects of dust exposure on lung function according to smoking habit. The coefficients for dust exposure and associated $t$ values describe separately these relations for the smoking group, whereas those for the effects of smoking on lung function describe the differences between smoking groups for consistency with the results described in table 2 .

Furthermore, analyses of 3007 men for whom approximate estimates of lifetime cigarette consumption had been made ( 2450 men who had smoked and 557 non-smokers) showed that the estimated effect of dust exposure was not sensitive to the way the effects of smoking were represented. For example, when smoking effects were represented simply as average differences between the three smoking groups, irrespective of age or amount smoked, the estimated dust effect (regardless of smoking habit) was $-0.69 \mathrm{ml} \mathrm{FEV} / \mathrm{gh} / \mathrm{m}^{3}(t=5.8)$. When different losses of $\mathrm{FEV}_{1}$ with age for the smoking groups were allowed, the estimated dust effect was $-0.68 \mathrm{ml} / \mathrm{gh} / \mathrm{m}^{3}(t=5.8)$. When the two variables for amount smoked were included (but not different age losses according to smoking categories), the estimated dust effect was $-0.69 \mathrm{ml} / \mathrm{gh} / \mathrm{m}^{3}(t=5.8)$, and when all these variables were simultaneously included $\frac{a}{z}$ the estimated dust effect was $-0.68 \mathrm{ml} / \mathrm{gh} / \mathrm{m}^{3}\left(t=\frac{\mathrm{D}}{\mathrm{D}}\right.$ 5.7). Both amount smoked and the different age effects according to smoking categories contributed $\overrightarrow{\vec{D}}$ to statistically significant improvements in the fit of $\frac{7}{0}$ these models to the lung function measurements.

The effect of dust exposure on lung function was $\frac{\overline{\bar{c}}}{\bar{c}}$ also clearly apparent even in the 2877 men without simple pneumoconiosis (categories $0 /-$ and $0 / 0$ ) at follow up survey. The regression coefficients for dust on exposure from the statistical model described in table $\vec{\circ}$ 2 when the analysis was confined to these men were $-1.06 \mathrm{ml} \mathrm{FEV} / \mathrm{gh} / \mathrm{m}^{3}(t=7.9 ; \mathrm{p}<0.0001)$, $-1.20 \mathrm{ml} \mathrm{FVC} / \mathrm{gh} / \mathrm{m}^{3}(t=8.3 ; \mathrm{p}<0.0001)$, and $-0.009 \% \mathrm{FEV}_{1} / \mathrm{FVC}$ ratio per $\mathrm{gh} / \mathrm{m}^{3}(t=4.0 ; \mathrm{p}<$ $0.001)$.

\section{COMPARISON OF MINERS AND EX-MINERS}

Men who had left the industry and were still under 65 근 at follow up had on average lower levels of $\mathrm{FEV}_{1}$ and $ᄋ$ $\mathrm{FEV}_{1} / \mathrm{FVC}$ ratio at follow up than working miners after allowing for other factors (table 2). Ex-miners 3 over 65 at follow up, many of whom had remained in the industry until compulsory retirement at 65 , had $\overrightarrow{0}$ lower mean $\mathrm{FEV}_{1} / \mathrm{FVC}$ ratios than miners, though not $\mathrm{FEV}_{1}$ or FVC after allowing for other factors.

Of greater interest, however, was whether exminers had responded differently to dust exposure from those who stayed in the industry. Considering the group of ex-miners under 65 as a whole, their lower level of function was not associated with a statistically significantly greater response to dust exposure than other men (table 4). Indeed, none of the differences in estimated dust effect between the three groups was statistically significant at the $5 \%$ level. Nevertheless, the magnitude of some of the differences were suggestive and encouraged more detailed analysis. For example (by addition of coefficients in table 4) the estimated effect of dust on $\mathrm{FEV}_{1}$ in ex-miners under 65 was $-0.89 \mathrm{mlFEV} / \mathrm{gh} / \mathrm{m}^{3}$ of exposure, whereas ex-

Table 4 Estimated effects of dust exposure in ex-miners. (These coefficients are taken from the statistical model described in table 2 after the addition of the terms for the effects of dust exposure in ex-miners)

\begin{tabular}{|c|c|c|c|c|c|c|}
\hline & \multicolumn{2}{|l|}{$F E V_{1}(\mathrm{ml})$} & \multicolumn{2}{|l|}{$F V C(m l)$} & \multicolumn{2}{|c|}{$F E V_{1} / F V C$ ratio (\%) } \\
\hline & Coefficient & $t$ & Coefficient & $t$ & Coefficient & $t$ \\
\hline $\begin{array}{l}\text { Effect of dust exposure in miners }\left(\mathrm{gh} / \mathrm{m}^{3}\right) \\
\text { Difference in effect of dust exposure } \\
\left(\mathrm{gh} / \mathrm{m}^{3}\right) \text { (compared with miners) }\end{array}$ & -0.68 & $-4 \cdot 5^{* * *}$ & -0.89 & $-5 \cdot 2^{* * *}$ & -0.002 & -0.6 \\
\hline $\begin{array}{l}\text { In ex-miners }<65 \\
\text { In ex-miners } \geqslant 65 \\
\text { Difference in mean level at zero }\end{array}$ & $\begin{array}{l}-0.21 \\
-0.06\end{array}$ & $\begin{array}{l}-0.9 \\
-0.3\end{array}$ & $\begin{array}{r}-0.25 \\
0.06\end{array}$ & $\begin{array}{r}-0.9 \\
0.3\end{array}$ & $\begin{array}{l}-0.003 \\
-0.006\end{array}$ & $\begin{array}{l}-0.7 \\
-1.7\end{array}$ \\
\hline $\begin{array}{l}\text { dust exposure (compared with miners) } \\
\text { In ex-miners }<65 \\
\text { In ex-miners } \geqslant 65\end{array}$ & $\begin{array}{r}-47 \\
30\end{array}$ & $\begin{array}{r}-1.0 \\
0.5\end{array}$ & $\begin{array}{r}-1 \\
24\end{array}$ & $\begin{array}{l}0.0 \\
0.4\end{array}$ & $\begin{array}{l}-1.5 \\
-0.4\end{array}$ & $\begin{array}{l}-0.9 \\
-0.4\end{array}$ \\
\hline
\end{tabular}


Table 5 Differences in mean level of lung function and effect of dust exposure between men with and without chronic bronchitis. (These coefficients are taken from the statistical model described in table 2 after addition of the terms described here)

\begin{tabular}{|c|c|c|c|c|c|c|}
\hline & \multicolumn{2}{|l|}{$F E V_{1}(m l)$} & \multicolumn{2}{|l|}{$F V C(m l)$} & \multicolumn{2}{|c|}{$F E V_{1} / F V C$ ratio (\%) } \\
\hline & Coefficient & $t$ & Coefficient & $t$ & Coefficient & $t$ \\
\hline $\begin{array}{l}\text { Difference in mean level at zero } \\
\text { dust exposure in men with chronic } \\
\text { bronchitis compared with men without }\end{array}$ & -358 & $-9 \cdot 5^{* * *}$ & -229 & $-5 \cdot 4^{* * *}$ & -5.975 & $-9 \cdot 2 * * *$ \\
\hline $\begin{array}{l}\text { Effects of dust exposure in men } \\
\text { without chronic bronchitis } \\
\text { Difference in effect of dust exposure } \\
\text { in men with chronic bronchitis } \\
\text { compared with men without }\end{array}$ & -0.54 & $\begin{array}{l}-4 \cdot 2^{* * *} \\
-0 \cdot 1\end{array}$ & $\begin{array}{l}-0.52 \\
-0.44\end{array}$ & $-3 \cdot 6^{* * *}$ & $\begin{array}{r}-0.005 \\
0.006\end{array}$ & $-2 \cdot 2^{*}$ \\
\hline
\end{tabular}

${ }^{*} 0.05>p \geqslant 0.01 ; * * * p<0.001$.

miners over 65 showed a more severe association between dust and $\mathrm{FEV}_{1} / \mathrm{FVC}$ ratio than did other men.

The need for more detailed analysis was confirmed when the effect of dust exposure was examined taking account of persistent cough and sputum. Men with chronic bronchitis had on average lower values of $\mathrm{FEV}_{1}, \mathrm{FVC}$, and $\mathrm{FEV}_{1} / \mathrm{FVC}$ ratio than other men (table 5). The effect of dust exposure on the $\mathrm{FEV}_{1}$ was similar in men with and without chronic bronchitis, but men with chronic bronchitis appeared to show a greater loss of FVC in relation to dust exposure than other men. A positive difference in $F E V_{1} / F V C$ ratio between these groups reflects these changes (table 5).

The differences in estimated dust effect indicated by tables 4 and 5 suggested that some men may have suffered a demonstrably greater effect of dust exposure than the average. To investigate this, the effects of dust exposure were examined in six groups of men distinguished by their employment status and presence of chronic bronchitis, since men may have been influenced in decisions about jobs by perception of their health and the influence of work on it. Table 6 shows that the estimated effect of dust exposure on the FVC was greatest in 453 ex-miners under 65 with chronic bronchitis - that is, $-1.14 \mathrm{ml} / \mathrm{FVC} / \mathrm{gh} / \mathrm{m}^{3}$ greater than the estimated effect in miners without chronic bronchitis. The greatest effect of dust on the $\mathrm{FEV}_{1}$ was also suggested in this group of men, but this difference might have arisen by chance $(0 \cdot 1>p$ $>0.05$ ). Estimated average differences in level of lung function confirm the association of chronic bronchitis

Table 6 Effects of dust exposure in six groups of men distinguished by their employment status and presence of chronic bronchitis. (The statistical model was similar to that described in table 2 with the addition or appropriate substitution of the terms described here)

\begin{tabular}{|c|c|c|c|c|c|c|}
\hline & \multicolumn{2}{|l|}{$F E V_{1}(m l)$} & \multicolumn{2}{|l|}{$F V C(m l)$} & \multicolumn{2}{|c|}{$F E V_{1} / F V C$ ratio $(\%)$} \\
\hline & Coefficient & $t$ & Coefficient & $t$ & Coefficient & $t$ \\
\hline $\begin{array}{l}\text { Effect of dust exposure }\left(\mathrm{gh} / \mathrm{m}^{3}\right) \text { in } 1134 \\
\text { miners without chronic bronchitis } \\
\text { Differences in effect of dust exposure } \\
\left(\mathrm{gh} / \mathrm{m}^{3}\right) \text { compared with miners } \\
\text { without chronic bronchitis in: } \\
733 \text { miners with chronic bronchitis }\end{array}$ & -0.51 & $-2 \cdot 6^{* *}$ & -0.60 & $-2 \cdot 7 * *$ & -0.001 & $-0 \cdot 3$ \\
\hline 570 ex-miners $<65$ without & 001 & -01 & דנת & & & \\
\hline $\begin{array}{l}\text { chronic bronchitis } \\
453 \text { ex miners < } 65 \text { with }\end{array}$ & 0.22 & 0.7 & 0.35 & $1 \cdot 0$ & -0.002 & $-0 \cdot 3$ \\
\hline $\begin{array}{l}\text { chronic bronchitis } \\
614 \text { ex-miners }>65 \text { without }\end{array}$ & -0.57 & -1.8 & $-1 \cdot 14$ & $-3 \cdot 1^{* *}$ & 0.003 & -0.5 \\
\hline $\begin{array}{l}\text { chronic bronchitis } \\
555 \text { ex-miners }>65 \text { with }\end{array}$ & $-0 \cdot 28$ & $-1 \cdot 0$ & $-0 \cdot 12$ & -0.4 & -0.010 & $-2 \cdot 0^{* *}$ \\
\hline chronic bronchitis & 0.29 & $1 \cdot 0$ & $0 \cdot 16$ & 0.5 & 0.002 & 0.5 \\
\hline $\begin{array}{l}\text { Differences in mean level at zero } \\
\text { dust exposure compared with } \\
\text { miners without chronic bronchitis in: } \\
\text { Miners with chronic bronchitis }\end{array}$ & -294 & $-5 \cdot 1 * * *$ & -158 & $-2 \cdot 4^{*}$ & $-4 \cdot 5$ & $-4 \cdot 5^{* * *}$ \\
\hline Ex-miners $<65$ without chronic & & & & & & \\
\hline $\begin{array}{l}\text { bronchitis } \\
\text { Ex-miners < } 65 \text { with chronic }\end{array}$ & -49 & -0.9 & -27 & -0.4 & -0.6 & $-0 \cdot 6$ \\
\hline $\begin{array}{l}\text { bronchitis } \\
\text { Ex-miners }>65 \text { without chronic }\end{array}$ & -331 & $-5 \cdot 0^{* * *}$ & -121 & $-1 \cdot 6$ & $-7 \cdot 3$ & $-6 \cdot 4^{* * *}$ \\
\hline $\begin{array}{l}\text { Ex-miners }>65 \text { without chronic } \\
\text { bronchitis }\end{array}$ & 127 & 1.9 & 148 & $2 \cdot 0^{*}$ & 0.9 & 0.8 \\
\hline $\begin{array}{l}\text { Ex-miners }>65 \text { with chronic } \\
\text { bronchitis }\end{array}$ & -408 & $-5 \cdot 8^{* * *}$ & -329 & $-4 \cdot 1^{* * *}$ & -6.8 & $-5 \cdot 6 * * *$ \\
\hline
\end{tabular}

${ }^{* 0.05}>p \geqslant 0.01 ;{ }^{* *} 0.01>p \geqslant 0.001 ; * * * p<0.001$. 
Table 7 Estimated effects of dust exposure in ex-miners under 65 grouped by their reasons for leaving the coal industry. (The coefficients are taken from the statistical model illustrated in table 2 and amplified as described in table 6, and after the addition or substitution of the terms described here)

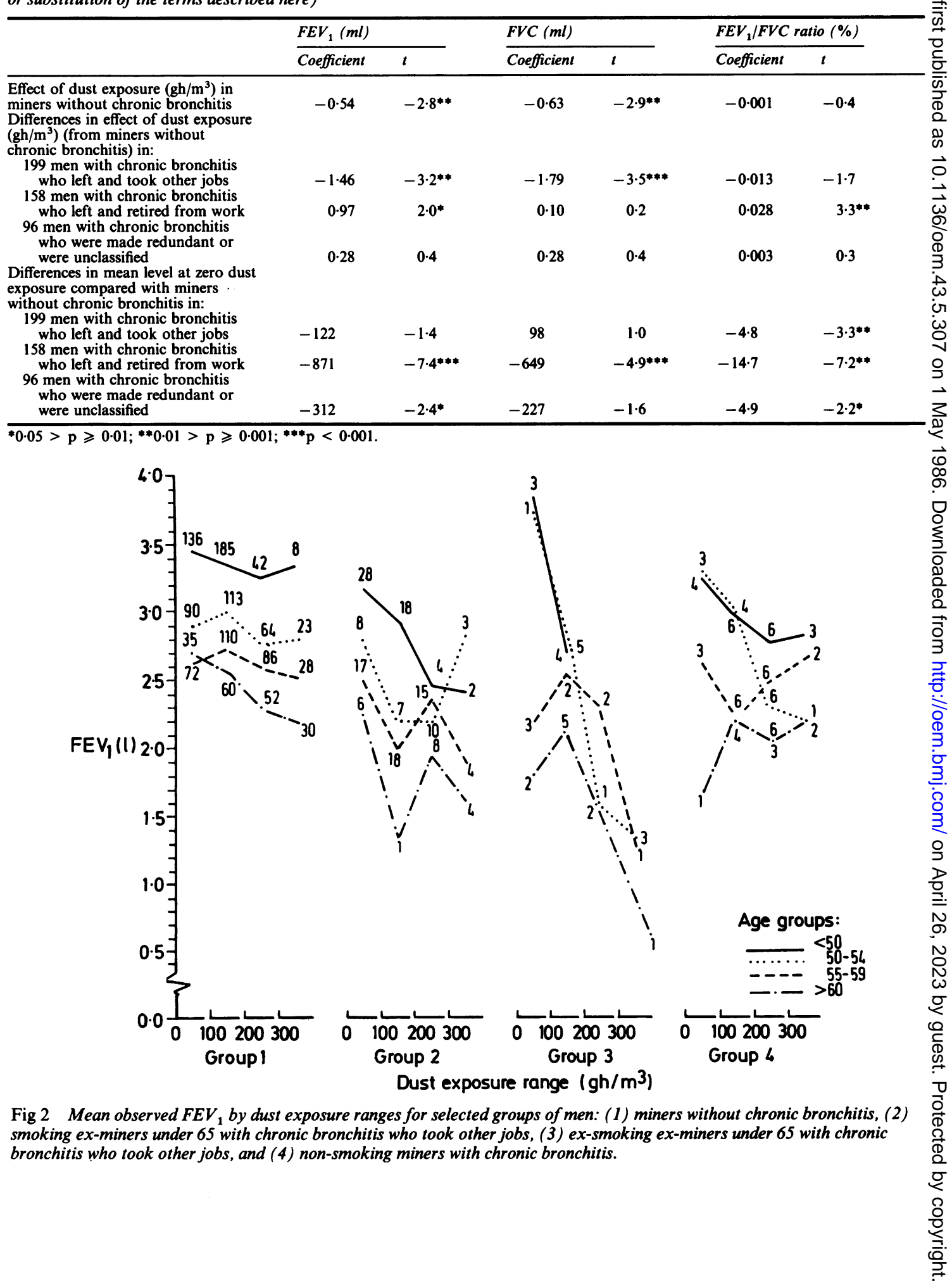


Table 8 Effects of dust exposure by smoking habit in two groups of men under 65 with chronic bronchitis who had left the industry. (The coefficients are taken from the statistical model described in table 2 and amplified as described in tables 6 and 7 , with the addition or appropriate substitution of the terms described here)

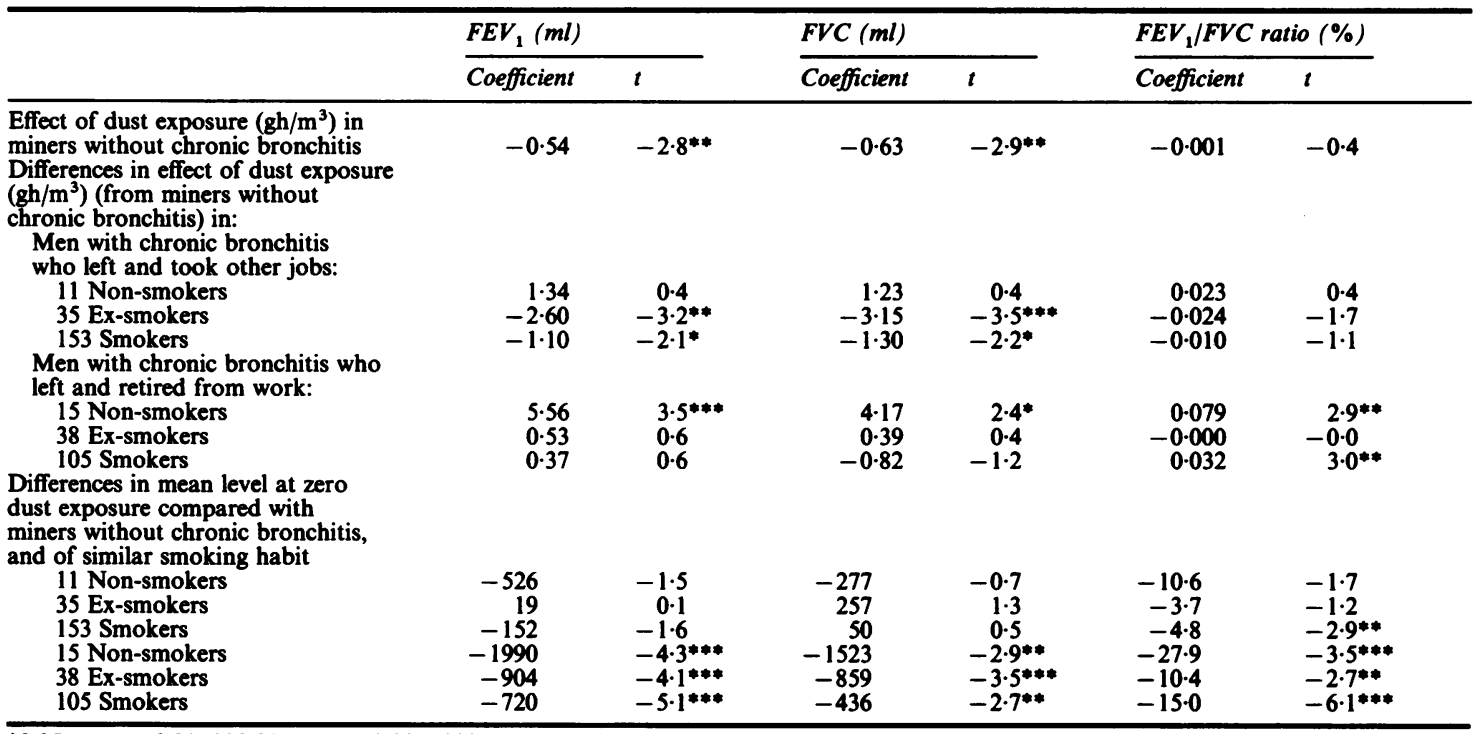

$0.05>p \geqslant 0.01 ;{ }^{* *} 0.01>p \geqslant 0.001 ;{ }^{* * *} p<0.001$.

with low levels of function after adjustment for possible differences in the effects of dust exposures (table 6).

These results suggested that among ex-miners under 65 with chronic bronchitis greater than average effects of dust exposure could be identified. These men were therefore examined in more detail, according to their reasons for leaving the industry and their subsequent employment, since such decisions could also be influenced by perceptions of health or ill health.

\section{EX-MINERS UNDER 65 WITH CHRONIC}

\section{BRONCHITIS}

The 453 ex-miners under 65 with chronic bronchitis comprised 158 who left voluntarily and did not take other jobs, 199 men who left voluntarily and took other work, and 96 who were made redundant or could not be classified in this respect.

Examination of these men (table 7) identified two especially interesting groups. In 199 men who left and took other jobs the mean levels of FEV 1 and FVC were not appreciably dissimilar from miners without chronic bronchitis (though they had a significant reduction of their $\mathrm{FEV}_{1} / \mathrm{FVC}$ ratio). They showed, however, a remarkably large estimated effect of dust exposure on their FEV 1 and FVC. The estimated effect on $\mathrm{FEV}_{1}$, for instance, was $-1.46 \mathrm{ml} \mathrm{FEV} / 1 / \mathrm{gh} / \mathrm{m}^{3}$ greater than for miners without chronic bronchitis, adding up to an absolute effect of $2.0 \mathrm{ml} \mathrm{FEV} / \mathrm{gh} / \mathrm{m}^{3}$ of exposure. The estimated effect on FVC was larger, adding up to an absolute effect of $-2.42 \mathrm{ml} \mathrm{FVC} / \mathrm{gh} / \mathrm{m}^{3}$. Analysis of this group by itself has been described elsewhere, ${ }^{6}$ and confirms the size and statistical significance of the estimated effect of dust exposure, which was not influenced by different ways of representing the effect of amount smoked. ${ }^{6}$

The second such group highlighted by table 7 comprised 158 men who had left the coal industry and retired from work. These men had much worse adjusted lung function than had miners without chronic bronchitis, of the order of 0.91 of FEV (table $^{2}$ 7). There was, however, no demonstrable adverse effect of dust exposure on $F_{E V}$ level in these men.

Further examination of the effects of dust exposure in these two groups of men according to smoking habit (fig 2 and table 8) shows that among the 199 men with chronic bronchitis who took other jobs, 35 ex-smokers showed the most severe estimated effects of dust exposure; $-2.60 \mathrm{ml} \mathrm{FEV} / / \mathrm{gh} / \mathrm{m}^{3}$ greater $(t=$ $3.5 ; p<0.01)$ than the effect on miners without chronic bronchitis or, by addition, an absolute effect of $-3 \mathrm{ml} / \mathrm{gh} / \mathrm{m}^{3}$, the corresponding figures for FVC being -3.15 and $-3.77 \mathrm{ml} / \mathrm{gh} / \mathrm{m}^{3}$. The 153 smokers still showed a substantial effect of dust exposure.

Figure 2 shows the observed values of the FEV ${ }_{1}$ for the 153 smokers and the 35 ex-smokers. Table 9 includes additional data for the 35 ex-smokers. The steep inverse relation between dust exposure and lung 
Table 9 Observed lung function values for 35 ex-smokers with chronic bronchitis who left mining for other jobs. Each cell contains: number of men, $F E V_{1}(l), F V C(l)$, and $F E V_{1} / F V C$ ratio (\%)

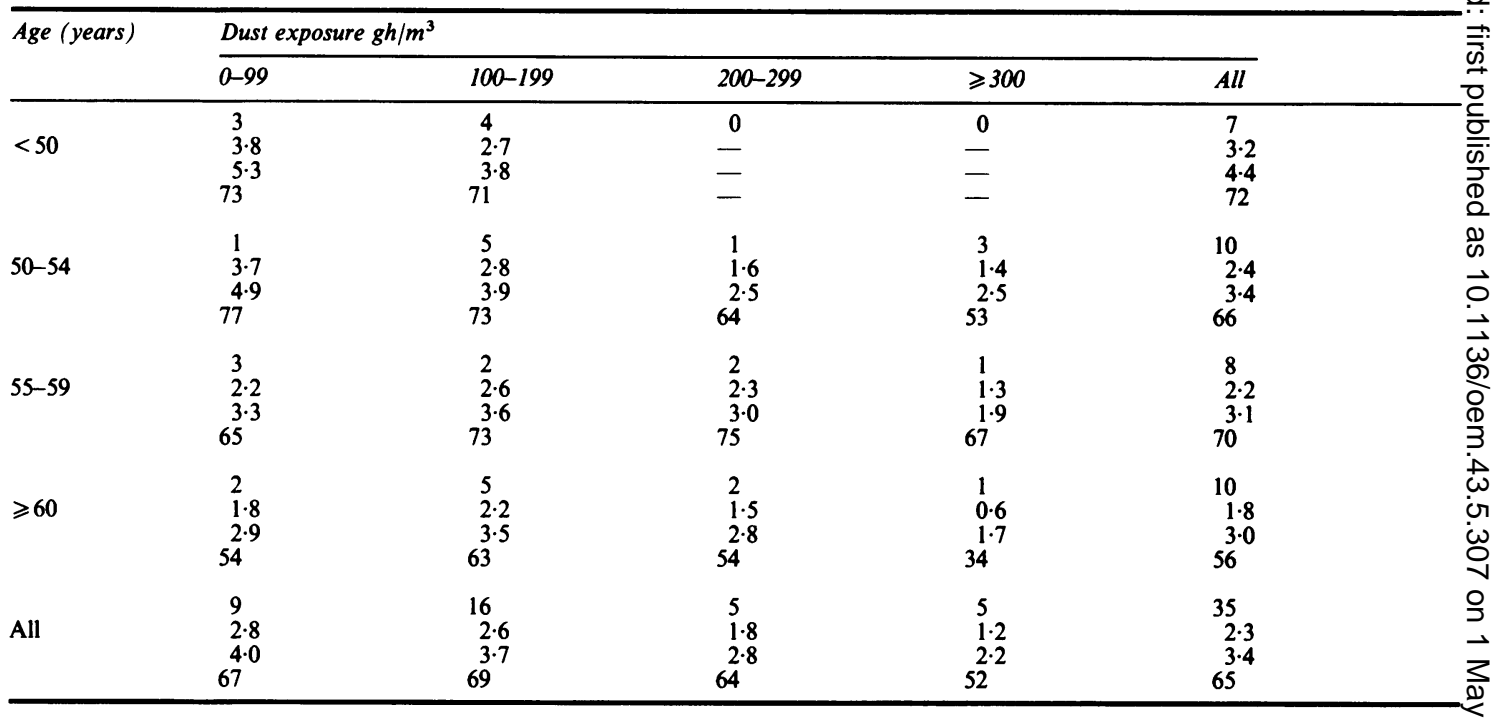

function is obvious in almost all age ranges for both groups of men.

Among 158 men under 65 with chronic bronchitis who retired prematurely and did not take other jobs, harmful effects of dust exposure were not obvious, although a positive relation between dust exposure and $F E V_{1} / F V C$ ratio among 105 smokers appears to result from a reduction of FVC in relation to dust exposure, which was of itself not statistically significant. A steep positive relation between duste exposure and the three functional variables in 15 non-o smokers was consistent with the observed data.

\section{EFFECTS OF DUST IN NON-SMOKERS}

Lifelong non-smokers are of special interest becauseg of the opportunity they present of studying the effects of dust exposure in the absence of smoking related damage. The relation between dust exposure and lung?

Table 10 Observed lung function values for 60 non-smoking miners with chronic bronchitis. Each cell contains: number of men, $F E V_{1}(l), F V C(l)$, and $F E V_{1} / F V C$ ratio (\%)

\begin{tabular}{|c|c|c|c|c|c|}
\hline \multirow[t]{2}{*}{ Age (years) } & \multicolumn{5}{|c|}{ Dust exposure gh/m $\mathrm{m}^{3}$} \\
\hline & $0-99$ & $100-199$ & $200-299$ & $\geqslant 300$ & All \\
\hline$<50$ & $\begin{array}{c}4 \\
3 \cdot 2 \\
4 \cdot 2 \\
79\end{array}$ & $\begin{array}{c}6 \\
3 \cdot 0 \\
4 \cdot 0 \\
73\end{array}$ & $\begin{array}{c}6 \\
2 \cdot 8 \\
3 \cdot 5 \\
79\end{array}$ & $\begin{array}{l}3 \\
2 \cdot 8 \\
4 \cdot 1 \\
70\end{array}$ & $\begin{array}{c}19 \\
2.9 \\
3.9 \\
76\end{array}$ \\
\hline $50-54$ & $\begin{array}{c}3 \\
3 \cdot 3 \\
4 \cdot 1 \\
81\end{array}$ & $\begin{array}{c}4 \\
3 \cdot 0 \\
4 \cdot 0 \\
75\end{array}$ & $\begin{array}{c}6 \\
2 \cdot 3 \\
3 \cdot 2 \\
73\end{array}$ & $\begin{array}{l}1 \\
2 \cdot 2 \\
2 \cdot 8 \\
80\end{array}$ & $\begin{array}{c}14 \\
2 \cdot 7 \\
3 \cdot 6 \\
76\end{array}$ \\
\hline $55-59$ & $\begin{array}{l}3 \\
2 \cdot 6 \\
3 \cdot 1 \\
86\end{array}$ & $\begin{array}{c}6 \\
2 \cdot 2 \\
3 \cdot 1 \\
73\end{array}$ & $\begin{array}{c}6 \\
2 \cdot 5 \\
3 \cdot 3 \\
73\end{array}$ & $\begin{array}{c}2 \\
2 \cdot 7 \\
3.6 \\
75\end{array}$ & $\begin{array}{c}17 \\
2 \cdot 4 \\
3 \cdot 2 \\
75\end{array}$ \\
\hline$\geqslant 60$ & $\begin{array}{l}1 \\
1 \cdot 7 \\
2 \cdot 4 \\
68\end{array}$ & $\begin{array}{c}4 \\
2 \cdot 2 \\
3 \cdot 0 \\
75\end{array}$ & $\begin{array}{c}3 \\
2 \cdot 0 \\
3 \cdot 1 \\
67\end{array}$ & $\begin{array}{c}2 \\
2 \cdot 2 \\
3 \cdot 1 \\
72\end{array}$ & $\begin{array}{c}10 \\
2 \cdot 1 \\
3 \cdot 0 \\
71\end{array}$ \\
\hline All & $\begin{array}{c}11 \\
3 \cdot 0 \\
3 \cdot 7 \\
80\end{array}$ & $\begin{array}{c}20 \\
2 \cdot 6 \\
3 \cdot 5 \\
74\end{array}$ & $\begin{array}{c}21 \\
2 \cdot 5 \\
3 \cdot 3 \\
74\end{array}$ & $\begin{array}{c}8 \\
2 \cdot 5 \\
3 \cdot 5 \\
73\end{array}$ & $\begin{array}{c}60 \\
2 \cdot 6 \\
3 \cdot 5 \\
75\end{array}$ \\
\hline
\end{tabular}


Table 11 Estimated losses of lung function related to a moderately high dust exposure of $300 \mathrm{gh} / \mathrm{m}^{3}$. (Estimates from relations that were not statistically significant $(p>0.05)$ are shown in parentheses)

\begin{tabular}{llcc}
\hline & $F E V_{1}(\mathrm{ml})$ & $F V C(m l)$ & $F E V_{1} / F V C$ ratio $(\%)$ \\
\hline All 4059 men & -228 & -276 & $-1 \cdot 5$ \\
Ex-miners with chronic bronchitis who & & & \\
took other jobs: & -492 & -579 & $(-3.0)$ \\
153 Smokers & -942 & -1134 & $(-7 \cdot 2)$ \\
35 Ex-smokers & -420 & -405 & $(-3.3)$ \\
\hline
\end{tabular}

function were therefore examined in non-smokers among the $\mathbf{4 0 5 9}$ men, subdivided according to presence of chronic bronchitis, miner/ex-miner status, and detailed employment status for ex-miners under 65 ; a total of ten groups of non-smokers.

The most severe negative estimated effect of dust exposure in non-smokers was in 60 non-smoking miners who admitted to symptoms of chronic bronchitis. The estimated (absolute) relations were $-1.40 \mathrm{ml} \mathrm{FEV} / \mathrm{gh} / \mathrm{m}^{3} \quad(t=2.0, \mathrm{p}>0.05)$; $-1.35 \mathrm{ml} \mathrm{FVC} / \mathrm{gh} / \mathrm{m}^{3}(t=1.8,0.1>\mathrm{p}>0.05)$ $-0.011 \% \mathrm{FEV}_{1} / \mathrm{FVC}$ ratio $(t=0.9, \mathrm{NS})$. Observed values of $\mathrm{FEV}_{1}$ for these men are shown in fig 2 and table 10. Non-smoking miners without chronic bronchitis also showed an adverse effect of dust exposure (coefficients $-0.93 \mathrm{mlFEV} / \mathrm{gh} / \mathrm{m}^{3}, t=2.0 ; \mathrm{p}<$ 0.05).

The observed lung function values of non-smoking miners with chronic bronchitis (table 10 and fig 2) show an obvious inverse relation of $\mathrm{FEV}_{1}$ with dust exposure in men under 55 , though over this age the relation is less obvious. The pattern of functional abnormality in this group regardless of age is considered below. A more severe effect of dust in younger men was not a general finding but was also suggested in 17 men under 55 among the 35 ex-smoking exminers who had taken other jobs (illustrated in table 9 and fig 2).

\section{MAGNITUDE AND TYPE OF LUNG FUNCTION} ABNORMALITY RELATED TO DUST EXPOSURE Some estimated effects of dust exposure on lung function are illustrated in table 11 . The overall average effect of even moderately high dust exposures is fairly mild in clinical terms (about $-230 \mathrm{ml}^{\text {of }} \mathrm{FEV}_{1}$ for an exposure of $300 \mathrm{gh} / \mathrm{m}^{3}$ ), but in ex-miners with chronic bronchitis who took other jobs the estimated effect of this exposure was large, and in the ex-smokers was severe (about $-940 \mathrm{ml}$ of $\mathrm{FEV}_{1}$ for this dust exposure). Some of the men did indeed have severe impairment of their lung function (table 9).

Non-smokers may also suffer reasonably severe effects of exposure to dust. The group with the most severe effect detected is shown in fig 2 and table 10 , and in these men the estimated effect of a moderately high dust exposure was a loss of about $-420 \mathrm{ml}$ of $\mathrm{FEV}_{1}$.

The estimated effects illustrated in table 11 show that dust exposure appears to be related to a characteristic pattern of lung function abnormality, causing a reduction of the FVC at least as much as the FEV and to be related to relatively little reduction of the FEV 1 FVC ratio. The effects of this are illustrated well by the observed lung function of the group of non-smokers shown in table 10 . In the smokers and ex-smokers, however, the added effects of the smoking habit superimposed on the effects of dust exposure results in an obstructive type of defect. Observed data for the ex-smokers are shown in table 9.

By contrast the average estimated effect of smoking in all 4059 men was to reduce the $\mathrm{FEV}_{1}$ more than the FVC, and to reduce the $\mathrm{FEV}_{1} / \mathrm{FVC}$ ratio substantially. The estimated average reduction of FVC at age 60 related to smoking was only 0.7 of the estimated reduction of $\mathrm{FEV}_{1}$ (calculated from the coefficients shown in table 2).

\section{Discussion}

This study has confirmed the observation ${ }^{1}$ reported more than a decade ago and supported by subsequent findings ${ }^{23} 1515 \mathrm{a}$ that chronic exposure to respirable coalmine dust is related to impairment of $F E V_{1}$ in coalminers. Our analyses of FVC and of the ratio $\mathrm{FEV}_{1} / \mathrm{FVC}$ have now established quantitative estimates of the relation of dust exposure with these characteristics also. We have also found that the relation between dust exposure and $F E V_{1}$ is similar in several parts of Britain, even where the exposures were relatively low5; that it is clear even in the absence of simple pneumoconiosis; and in general is independent of smoking habit.

These estimated effects of dust exposure were not confused with the effects of smoking, for the estimates of dust effect were not sensitive to the way the effects of smoking were allowed for and were still apparent even when smoking was taken into account in the most detailed way the data permitted. Furthermore quite profound effects of dust exposure were found among non-smokers. 
The previous estimate ${ }^{1}$ of the effect of dust exposure on the lung function of British miners was based on colliery faceworkers only. The subjects of the present study are more diverse, including men employed in all the non-sedentary occupations at each colliery at the time of survey and many who had left the industry by that time. The present study also has the advantages of using dust exposures based on longer periods of measurement than previously ${ }^{1}$ and of representing the effects of smoking and of regional differences more comprehensively than before.

In view of these differences, the overall estimate in the present study of an impairment of $0.76 \mathrm{ml} \mathrm{FEV}_{1}$ per unit of dust exposure is remarkably similar to that of $0.60 \mathrm{ml} \mathrm{FEV}$ reported previously.

The present study group, however, is still not fully representative of British miners. All those considered for inclusion in the analyses reported now had remained in the industry for at least ten years, from the 1950s onwards, and so were presumably healthier than others among the original parent sample of 17738 men. Within this ten year survivor group all those with the specific dust related lung disease of progressive massive fibrosis were excluded from study. Losses to follow up because of death or other causes during the subsequent 11 years are also likely to have been biased towards the exclusion of ill men. This issue is being examined further.

The analysis described here investigates the associations between exposure to respirable dust and lung function. The interpretation of a statistically significant association depends on the wider context of the result. In the present instance the rationale underlying the entire research programme is that dust exposure may cause lung damage. The exposure measurements refer to periods before the lung function measurements, and every attempt has been made to take account of possible confusing factors and associations. Thus when an inverse association between exposure to dust and lung function is shown, it is reasonable to assume causality until a tenable alternative explanation is proposed.

In the context of this slightly selected but otherwise diverse group of coalminers our main interest was in whether those who had left the industry had experienced a more severe response to dust than those who remained. Certainly the ex-miners were less healthy; and overall their estimated response to dust exposure was slightly more severe than that of the miners, but not statistically significantly so. An excessive effect of dust exposure was, however, shown by a small subgroup of the ex-miners.

Whereas the published evidence for an association between exposure to respirable dust and lung function is clear, the clinical importance of the effects of dust exposure has been the subject of debate. ${ }^{16-18}$
One unknown issue has been to what extent some men may suffer a greater than average effect of dust exposure. By examining in this study groups who a priori might be expected to include such men, characterised by their respiratory symptoms and reasons for leaving the industry (there is evidence from another dusty industry that men who leave before normal retiral age tend to have suffered greater decline of FEV $_{1}$ than their fellows ${ }^{19}$ ), we have identified some where the estimated relation between dust exposure and lung function is much more severe than average. For example, the estimated overall effect of a moderately high dust exposure for this group $\left(300 \mathrm{gh} / \mathrm{m}^{3}\right)$ in the 199 men with chronic bronchitis who took other jobs was a loss of 0.61 of $\mathrm{FEV}_{1}$. A more severe response was shown by the ex-smokers in the group: $0.91 \mathrm{FEV}_{1}$ for the same exposure, and probably these men had been influenced in their decision to give up smoking (as well as change their job) by awareness of ill health. An alternative hypothesis would be that giving up smoking in some way precipitated an accelerated response to dust exposure. The data relating to younger men in this subgroup hint that even more severe responses to dust exposure may be possible.

The statistical significance of the differences in dust effect between these groups and the remainder of the 4059 men strongly suggest that the differences are not attributable to chance. This view is supported by the results of a simulation exercise on selected analyses. ${ }^{6}$

The 15 non-smoking ex-miners under 65 with chronic bronchitis who had retired prematurely and who showed a pronounced positive relation between $\mathrm{FEV}_{1}$ and dust exposure were quite untypical of nonsmokers as a whole, who consistently showed a negative relationship. These 15 men suffered from chronic bronchitis, rare in non-smokers, and had retired prematurely from all work. Possibly, some of them suffered from diseases associated with poor lung function (such as asthma), which had caused them to avoid both the smoking habit and dusty working conditions, and had also caused them to retire early. Such a group would be likely to show the positive relation between dust exposure and lung function shown here. Some support for this hypothesis was found from the answers to the questionnaire of respiratory symptoms administered at follow up survey. Wheeze is one of of the cardinal symptoms of asthma and one of the ques- $N$ tions was "Do you ever have wheezing or whistling in your chest?-I don't mean only when you have a cold." The frequency with which this question was answered positively by the 514 non-smokers in the whole study group was $34 \%$, whereas 14 of the $15 \cong$ non-smokers in this selected group gave a positive answer $(93 \%)$. While this is not conclusive evidence that these men suffered from asthma, it would be consistent with a high frequency of asthma among them. 
Thus it is possible to conceive a mechanism by which selection might have accounted for the positive relation between $\mathrm{FEV}_{1}$ and dust exposure in these 15 non-smokers. It is difficult to think how selection might have caused the severe negative relations between $\mathrm{FEV}_{1}$ and dust exposure in some groups, other than by selecting men in whom dust exposure had caused the severe loss of $\mathrm{FEV}_{1}$. For these reasons we believe that these steep negative relations between $\mathrm{FEV}_{1}$ and dust exposure represent true harmful effects of dust exposure on lung function.

While the severe dust effect in the 199 ex-miners under 65 with chronic bronchitis who took other jobs and in the 35 ex-smokers among them are certainly not typical of coalminers generally, we do consider it representative of what can and does occur among susceptible men. Such men showing excessive responses to exposure to respirable dust may be fairly rare, for severe effects of dust exposure were shown only in some members of a highly selected small group comprising $5 \%$ of the whole study population. On the other hand, the restriction of the study group to men who remained in the coal industry for 11 years after they were first examined may have excluded some ill men, and this would be consistent with the suggestion from the data that the most severe effects of dust occurred in younger men.

The pattern of effects of dust exposure on the FEV $_{1}, \mathrm{FVC}_{\text {, and }} \mathrm{FEV}_{1} / \mathrm{FVC}$ ratio suggest that the functional effects of dust induced lung damage are different from those of smoking. While smoking was related to a classic obstructive defect, exposure to dust was related to a parallel reduction of $F E V_{1}$ and FVC which we interpret as indicating damage at the level of the respiratory bronchiole or alveolus. This would be consistent with the finding of increased residual volume in coalminers, ${ }^{20}$ but it appears to conflict with other results which have been interpreted as indicating that the effect of dust on the lungs is principally on the upper airways. ${ }^{21}$

This characteristic pattern of abnormality was illustrated well by the group of non-smokers we have described here, but in the smokers and ex-smokers severely affected by their dust exposure the resulting type of abnormality was predominantly the obstructive pattern, no doubt the result of the additional influence of smoking. Possibly these functional changes indicate the presence of emphysema, for pathological evidence suggests that centriacinar emphysema in coalminers is related to dust as well as to smoking. ${ }^{22}$ These men, if presenting to a physician, would appear to have classic airflow obstruction, and their disease could easily and mistakenly be attributed solely to their smoking habit.

In general the effect of dust on lung function was not affected by smoking habit, and the reason for the excessive effect of dust in some men must be sought elsewhere. A third factor (or more), whether intrinsic susceptibility to the effects of dust or an environmental factor not so far identified, must be sought to explain why these men suffered such severe lung damage in response to their exposure to respirable dust.

This research has been undertaken over a period of seven years, and many of our colleagues have made substantial contributions to it which we gratefully acknowledge. We also thank the many current and retired miners who took part, and also D Gurr, L Munro, and $H$ Collins for help with the statistical analysis and D Annis for work on the dust concentrations data.

This work was supported by the British National Coal Board and the Commission of the European Communities (contract No 7246-16/8/002.)

\section{References}

${ }^{1}$ Rogan JM, Attfield MD, Jacobsen M, Rae S, Walker DD, Walton WH. Role of dust in the working environment in development of chronic bronchitis in British coal miners. $\mathrm{Br} \mathrm{J}$ Ind Med 1973;30:217-26.

${ }^{2}$ Reichel G, Ulmer WI. Chronic bronchitis and occupational dust exposure. Boppaid: Harold Boldt Verlag KG, 1978:224-91.

${ }^{3}$ Hankinson JL, Reger RB, Fairman RP, Lapp NL, Morgan WKC. Factors influencing expiratory flow rates in coal miners. In: Walton WH, ed. Inhaled particles IV. Oxford: Pergamon Press, 1977:737-55.

${ }^{4}$ Rogan JM, Rae S, Walton WH. The National Coal Board's pneumoconiosis field research-an interim review. In: Inhaled particles and vapours II. Oxford \& New York: Pergamon Press, 1966:493-508.

${ }^{5}$ Soutar CA, Hurley JF, Gurr DC. The relationship between dust exposure and lung function in miners and ex-miners. In: Sixth international pneumoconiosis conference 1983, Bochum-Federal Republic of Germany. Geneva: International Labour Organisation, 1984:390-6.

${ }^{6}$ Hurley JF, Soutar CA. Can exposure to coal mine dust cause a severe impairment of lung function? $\mathrm{Br} J$ Ind Med 1986; 43:150-7.

${ }^{7}$ Maclaren WM, Soutar CA. Progressive massive fibrosis and simple pneumoconiosis in ex-miners. Br J Ind Med 1985;42:734-40.

${ }^{8}$ Miller BG, Jacobsen M. Dust exposure, pneumoconiosis and coalminers' mortality. Br J Ind Med 1985;42:723-33.

${ }^{9}$ Rae S, Walker DD, Attfield MD. Chronic bronchitis and dust exposure in British coalminers. In: Walton WH, ed. Inhaled particles III. Old Woking, Surrey: Unwin Bros, 1971:883-94.

${ }^{10}$ Copland L, Burns J, Jacobsen M. Classification of chest radiographs for epidemiological purposes by people not experienced in the radiology of pneumoconiosis. $\mathrm{Br} J$ Ind Med 1981;38: 254-61.

${ }^{11}$ International Labour Office. ILO U/C international classification of radiographs of the pneumoconiosis, 1971. Geneva: ILO, 1972. (Occupational safety and health series No 22.)

12 Orenstein AJ. Recommendations adopted by the pneumoconiosis conference. In: Orenstein AJ, ed. Proceedings of the pneumoconiosis conference, Johannesburg 1959. London: J \& A Churchill, 1960:619.

${ }^{13}$ Dodgson J, Hadden GG, Jones CO, Walton WH. Characteristics of the airborne dust in British coalmines. In: Walton WH, ed. Inhaled particles III. Old Woking, Surrey: Unwin Bros, 1971: 757-82. 
${ }^{14}$ Hurley JF, Burns J, Copland L, Dodgson J, Jacobsen M. Coalworkers simple pneumoconiosis and exposure to dust at 10 British coalmines. Br J Ind Med 1982;39:120-7.

${ }^{15}$ Love RG, Miller BG. Longitudinal study of lung function in coal miners. Thorax 1982;37:193-7.

15. Attfield MD. Longitudinal decline in $\mathrm{FEV}_{1}$ in United States coalminers. Thorax 1985;40:132-7.

${ }^{16}$ Anonymous. Occupation and bronchitis (Editorial). Lancet 1980;i:235-6.

${ }^{17}$ Morgan WKC, Lapp NL, Seaton D. Respiratory disability in coalminers. JAMA 1980;243:2401-4.
${ }^{18}$ Jacobsen M. Smoking and disability in miners. Lancet 1980;i:740.

${ }^{19}$ Eisen EA, Wegman DH, Louis TA. Effects of selection in a prospective study of forced expiratory volume in Vermont granite workers. Am Rev Respir Dis 1983;128:587-91.

${ }^{20}$ Morgan WKC, Burgess DB, Lapp NL, Seaton A. Hyperinflation of the lungs in coalminers. Thorax 1971;26:585-90.

${ }^{21}$ Hankinson L, Reger RB, Morgan WKC. Maximal expiratory flows in coal miners. Am Rev Respir Dis 1977;116:175-80.

${ }^{22}$ Ruckley VA, Gauld SJ, Chapman JS, et al. Emphysema and dust exposure in a group of coal workers. Am Rev Respir Dis 1984; 129:528-32.

\section{Vancouver style}

All manuscripts submitted to the $\mathrm{Br} J$ Ind $\mathrm{Med}$ should conform to the uniform requirements for manuscripts submitted to biomedical journals (known as the Vancouver style).

The $\mathrm{Br} J$ Ind Med, together with many other international biomedical journals, has agreed to accept articles prepared in accordance with the Vancouver style. The style (described in full in $\mathrm{Br}$ Med J, 24 February 1979, p 532) is intended to standardise requirements for authors.

References should be numbered consecutively in the order in which they are first mentioned in the text by Arabic numerals above the line on each occasion the reference is cited (Manson' confirmed other reports ${ }^{2-5} \ldots$.). In future references to papers submitted to the $\mathrm{Br} J$ Ind Med should include: the names of all authors if there are six or less or, if there are more, the first three followed by et al; the title of journal articles or book chapters; the titles of journals abbreviated according to the style of Index Medicus; and the first and final page numbers of the article or chapter.

Examples of common forms of references are:

' International Steering Committee of Medical Editors. Uniform requirements for manuscripts submitted to biomedical journals. Br Med J 1979; 1:532-5.

2 Soter NA, Wasserman SI, Austen KF. Cold urticaria: release into the circulation of histamine and eosinophil chemotactic factor of anaphylaxis during cold challenge. $N$ Engl J Med 1976;294:687-90.

${ }^{3}$ Weinstein L, Swartz MN. Pathogenic properties of invading micro-organisms. In: Sodeman WA Jr, Sodeman WA, eds. Pathologic physiology: mechanisms of disease. Philadelphia: W B Saunders, 1974:457-72. 